\title{
Assessing impact of eucalyptus plantations on benthic macroinver- tebrate communities by a litter exclusion experiment
}

\author{
A. Larrañaga*, S. Larrañaga, A. Basaguren, A. Elosegi, J. Pozo \\ Department of Plant Biology and Ecology, Faculty of Science and Technology, University of the Basque Country, P.O. Box 644, E-48080 Bilbao, \\ Spain
}

\begin{abstract}
To test whether leaf litter from eucalyptus plantations affects stream macroinvertebrate communities, we manipulated litter inputs into a small headwater tributary of the Agüera stream (northern Spain) running under mixed deciduous forests. Three contiguous $50 \mathrm{~m}$ long reaches were used: the upstream reach was left as a control (site C), whereas the two downstream sites were covered by $1 \mathrm{~mm}$ mesh nets to avoid natural litter inputs, and twice a month received litter collected at a deciduous forest (site D, mid) or a eucalyptus plantation (site E, downstream). Benthic Surber samples were taken from the three sites before and after the treatment and density, biomass and structure of the community were compared. Density and biomass of macroinvertebrates did not differ among sites before the treatment. Total density and biomass of macroinvertebrates increased in all the sites during the experimental period but most considerably at the site were deciduous forest inputs were simulated (station D). At the end of the experiment shredders were significantly less abundant at site $\mathrm{E}$ (eucalyptus) than at site D (deciduous). In addition, shredder density and biomass per total organic matter amount and per total leaf amount became higher at site D. In conclusion, these results suggest a subtle negative impact of eucalyptus litter on stream macroinvertebrate communities, especially on shredders.
\end{abstract}

Keywords : Eucalyptus plantations, streams, macroinvertebrates, litter exclusion

\section{Introduction}

Macroinvertebrate communities of forested streams depend on allochthonous organic matter because autochthonous production is light-limited (Tait et al. 1994). Substitution of native riparian forests by exotic plantations can change the amount, temporal distribution and quality of litter entering the stream (Royer et al. 1999, Molinero \& Pozo 2004). The community of macroinvertebrates could respond to this substitution by changing their structure (e.g. density, taxonomic richness) or even ecosystem functioning (e.g. litter processing, secondary production) (Richardson 1991, Hall et al. 2000).

\footnotetext{
* Corresponding author :

E-mail: gvblaara@1g.ehu.es
}

Eucalyptus globulus Labill. plantations cover great areas in the Iberian Peninsula (ICONA 1980, Paiva 1992). Eucalyptus, unlike autochthonous species of the area (northern Spain), is an evergreen tree whose litter falls throughout the year, peaking in summer (Lamb 1985, Pozo et al. 1997). This difference on the pattern of leaf fall, and thus on the inputs of organic matter, could impact taxa with life cycles synchronized with the autumnal litter fall of deciduous species (Giller \& Twoney 1993, Graça 2001). In addition, eucalyptus litter contains high amounts of inhibitory compounds such as phenols, tannins and oils (Barlöcher et al. 1995), thick cuticle and low quantity of nitrogen and phosphorus (O'Connel \& Menagé 1982, Pozo 1993), which can delay leaf colonization by aquatic hyphomycetes (Chauvet et al. 1997). Nevertheless, conclusions about the effects of eucalyptus plantations

Article available at http://www.limnology-journal.org or http://dx.doi.org/10.1051/limn/2006002 
on detritivorous macroinvertebrates are not clear. Colonization of eucalyptus leaves by macroinvertebrates is slower than that of deciduous litter in nutrient poor reaches (Basaguren \& Pozo 1994), but differences tend to disappear with more time of conditioning (González et al. 1998) or when dissolved nutrients in the stream water are higher (Pozo et al. 1998). On the other hand, Abelho \& Graça (1996) pointed out that macroinvertebrate diversity and density in Portuguese rivers flowing through eucalyptus plantations were lower than under autochthonous forests, but such differences were not so evident in northern Spain (see Otermin et al. 2002, González et al. 2003b). Nevertheless, field studies like those previously cited are often inconclusive because differences in lithology, channel form or water chemistry among sites can hide the effects generated by surrounding vegetation changes.

The aim of this work was to study the effects of eucalyptus litter on the composition and structure of stream macroinvertebrate communities, using a manipulative approach to avoid the effect of concomitant variables.

\section{Material and methods}

\section{Study site}

This study was conducted in a homogeneous 200 metre long reach of a small tributary of Salderrey stream, situated in the upper part of the Agüera river basin (northern Spain), at $500 \mathrm{~m}$ a.s.l. (stream A in Bañuelos et al. 2004). It drains a siliceous basin of ca. 25 ha covered by mixed mature forest of oak (Quercus robur L.), chestnut (Castanea sativa Miller) and alder (Alnus glutinosa (L.) Gaertner). Climate is temperate oceanic with mean annual temperature of $14.3^{\circ} \mathrm{C}$ (range of $9.8-20.3^{\circ} \mathrm{C}$ ) and an annual precipitation of
$1650 \mathrm{~mm}$ mainly in form of rain (Elosegi et al. 2002). Hydrologic regime of the stream is irregular with high discharge episodes throughout the year (Fig. 1). Very low discharge values were registered from June 1999 to October 1999. Mean width and depth of the stream were 85 and $5 \mathrm{~cm}$ respectively. Physico-chemical variables measured in the reach during the experimental period gave mean values of $12.1^{\circ} \mathrm{C}$ of water temperature, a $\mathrm{pH}$ of $7,146 \mu \mathrm{S} / \mathrm{cm}$ of conductivity, $97 \%$ of oxygen saturation, and $756.8 \mu \mathrm{gN} / 1$ of nitrate, $3.4 \mu \mathrm{gN} / 1$ of nitrite, $25.2 \mu \mathrm{gN} / 1$ of ammonia and $9.6 \mu \mathrm{gP} / 1$ of phosphate concentration in water.

\section{Experimental design}

Three contiguous reaches of about $50 \mathrm{~m}$ long were selected (10 metres of separation distance). The uppermost, site C (control), was used as a reference site whereas the other two, D (deciduous) and E (eucalyptus), were covered with 1-mm mesh net to avoid litter inputs from surrounding forest. Openings were left on the laterals to allow natural movements of aerial insects. A series of wire meshes were placed transversally to the current to avoid litter inputs to the reaches by transport (upstream), and to collect litter exported from the sites (downstream). Minimum mesh size used in these transversal nets was $16 \mathrm{~mm}$. All transversal nets were frequently cleaned to avoid clogging. A period of 5 months (January 2000 - May 2000) was used to fit the methodology to the characteristics of the stream.

\section{Inputs of leaf litter}

From May 2000 to January 2001, inputs to sites D and $\mathrm{E}$ were manipulated. Material captured by 1-mm mesh traps in an area equivalent to the streambed covered by nets was added to each site. The source of the litter for site $\mathrm{D}$ was the surrounding deciduous forest

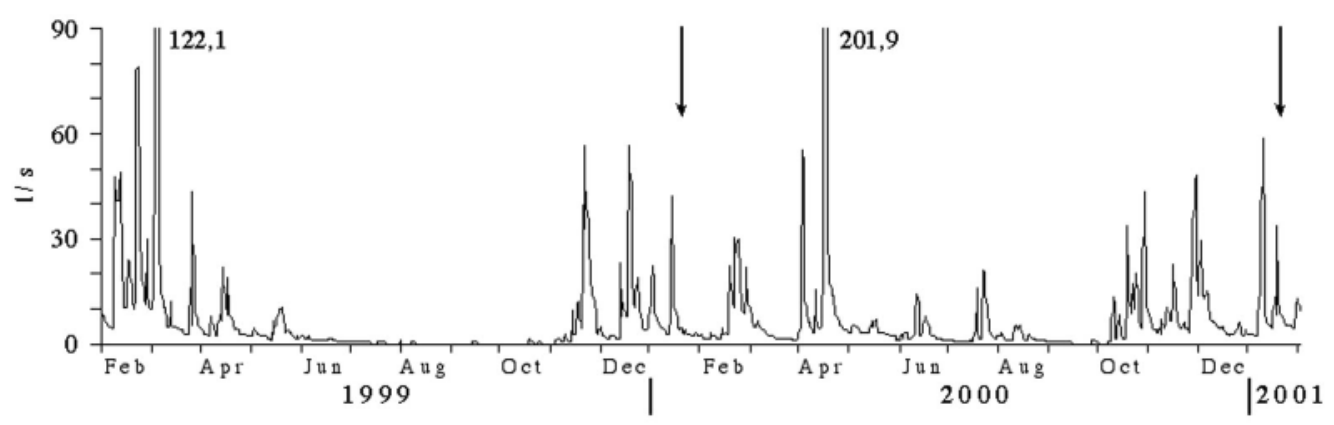

Fig. 1. Daily discharge from February 1999 to January 2001. Arrows point the sampling dates. 
and for site $\mathrm{E}$ an eucalyptus plantation of the region. Material so gathered was weighed and distributed homogeneously along the corresponding site twice a month. Site D received 388.16 g AFDM of total organic matter during the experiment, including $281.78 \mathrm{~g}$ AFDM of leaf material (mainly oak). On the other hand, site E received $581.74 \mathrm{~g}$ AFDM of total organic matter, being 370.45 of that leaf material (nearly all eucalyptus).

\section{Sampling}

Benthic invertebrates were sampled in January 2000 , before the manipulative experiment, and in January 2001, a year later (seven months of experimental treatment). Five surbers $\left(0.09 \mathrm{~m}^{2}, 0.2 \mathrm{~mm}\right.$ mesh $)$ were collected at randomly selected points in each occasion. In the laboratory samples were washed through $1 \mathrm{~mm}$ and $0.2 \mathrm{~mm}$ nested sieves. Organic matter present in the samples of sites D and E was separated in categories (leaves by species, twigs and bark, fruit and flowers, and other detritus). At site $\mathrm{C}$ only bulk organic matter was measured; we supposed its composition would be similar to that of site $\mathrm{D}$, because at both sites it came from the same source forest. The amount of organic matter was expressed as ash free dry mass (AFDM) after drying $\left(70^{\circ} \mathrm{C}, 72 \mathrm{~h}\right)$ and ashing $\left(500{ }^{\circ} \mathrm{C}, 12 \mathrm{~h}\right)$ the material. Macroinvertebrates were sorted, identified and counted under a binocular stereomicroscope. Taxa were assigned to functional feeding groups according to Merritt \& Cummins (1996). Biomass for each functional group was measured in terms of dry mass, after drying at $70^{\circ} \mathrm{C}(72 \mathrm{~h})$ and weighing with an analytic balance (accuracy : $10 \mu \mathrm{g}$ ).

\section{Data analysis}

Previous to statistical analysis data were normalized with a $\log (\mathrm{x}+1)$ transformation. Student's unpaired $\mathrm{t}$ test was used to look for temporal changes at each site. Differences between sites within each sampling date were tested using one-way ANOVA and Tukey test for multiple-comparisons (Zar 1999). Collector-gatherers and shredders, comprising more than $10 \%$ and $1 \%$ of total macroinvertebrate abundance respectively, were treated statistically and are called relevant taxa throughout the text (Chironomidae, Oligochaeta, Leuctra, Nemoura, Protonemura, Echinogammarus and Limnephilidae). Invertebrate density and biomass per total organic matter or per total leaf amount was calculated for each surber to express it as Ind/g AFDM or $\mathrm{mg} / \mathrm{g}$ AFDM.

\section{Results}

\section{Organic matter}

In January 2000, before the onset of litter exclusion, the amount of benthic organic matter showed no significant differences among sites, although mean values of more than $800 \mathrm{~g} \mathrm{AFDM} / \mathrm{m}^{2}$ at site $\mathrm{C}$ and less than $120 \mathrm{~g} \mathrm{AFDM} / \mathrm{m}^{2}$ at sites D and $\mathrm{E}$ were observed. A similar pattern of interannual increase was found at all reaches, but this was only significant at site E. In January 2001, the amount of organic matter at site $\mathrm{C}$ was significantly higher than at sites D and E. Despite the exclusion of deciduous organic matter at site E, only $41 \%$ of CPOM was eucalyptus litter in this reach in January 2001.

\section{Composition and structure of macroinvertebrate communities}

In January 2000 taxa richness varied from 22 (site C) to 28 and 27 (sites D and E, respectively) (Fig. 2). No significant differences were found in density and biomass of total macroinvertebrates among sites (Fig. 3; table 1). None of the functional groups differed significantly in density and biomass among sites, with the exception of gatherers, which were more abundant at site E than at C (Fig. 3; table 1). All relevant taxa were statistically similar at all sites at the beginning of the experiment. The only exception were oligochaetes, which were more abundant at site $\mathrm{E}$ than at $\mathrm{C}$.

After one year (January 2001) the taxonomic richness did not change at site $\mathrm{C}$ but increased to 40 and 32 taxa at sites D and E respectively (Fig. 2). Density and biomass of total macroinvertebrates were similar at the three sites (table 1), but functional feeding groups showed more differences than in the previous year. Densi-

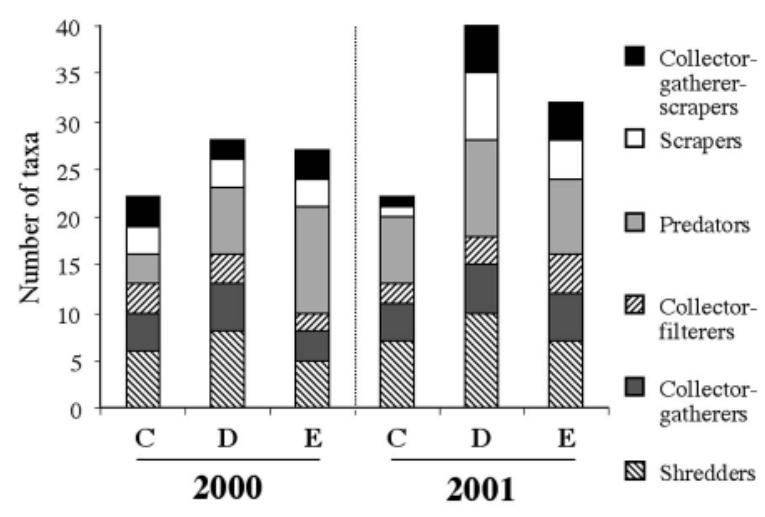

Fig. 2. Taxonomic richness at sites $\mathrm{C}$ (control), D (deciduous) and $\mathrm{E}$ (eucalyptus) before (2000) and after (2001) the experimental treatment. 
Table 1. Results of one-way ANOVA and multiple comparisons with Tukey test for invertebrate density and biomass among sites $\mathrm{C}$ (control), D (deciduous) and $\mathrm{E}$ (eucalyptus) in 2000 and 2001. Short lines above letters join sites that do not differ statistically $(\mathrm{p}>0.05)$. Sites are ordered from low (left) to high (right). * : $\mathrm{p}<0.05 ; * *: \mathrm{p}<0.01 ; * * *: \mathrm{p}<0.001 ; \mathrm{ns}:$ no significant.

\begin{tabular}{|c|c|c|c|c|c|c|c|c|}
\hline & \multicolumn{4}{|c|}{2000} & \multicolumn{4}{|c|}{2001} \\
\hline & \multicolumn{2}{|c|}{ Density } & \multicolumn{2}{|c|}{ Biomass } & \multicolumn{2}{|c|}{ Density } & \multicolumn{2}{|c|}{ Biomass } \\
\hline & $\mathbf{p}$ & Tukey & p & Tukey & p & Tukey & $\mathbf{p}$ & Tukey \\
\hline Total macroinvertebrates & ns & $\overline{\mathrm{CDE}}$ & ns & $\overline{\mathrm{DEC}}$ & ns & $\overline{\mathrm{ECD}}$ & ns & $\overline{\mathrm{EDC}}$ \\
\hline Shredders & ns & $\overline{\mathrm{CDE}}$ & ns & $\overline{\mathrm{DEC}}$ & $* * *$ & $\overrightarrow{\mathrm{CED}}$ & $*$ & $\overline{\mathrm{ED}} \mathrm{C}$ \\
\hline Collector-gatherers & $*$ & $\overline{\mathrm{CDE}}$ & ns & $\overline{\mathrm{CDE}}$ & ns & $\overline{\mathrm{DEC}}$ & ** & $\overline{\mathrm{DE}} \mathrm{C}$ \\
\hline Collector-filterers & ns & $\overline{\mathrm{ECD}}$ & ns & $\overline{\mathrm{EDC}}$ & ns & $\overline{\mathrm{CDE}}$ & ** & $\mathrm{C} \overline{\mathrm{DE}}$ \\
\hline Predators & ns & $\overline{\mathrm{CDE}}$ & ns & $\overline{\mathrm{DCE}}$ & ns & $\overline{\mathrm{EDC}}$ & ns & $\overline{\mathrm{DEC}}$ \\
\hline Scrapers & ns & $\overline{\mathrm{DCE}}$ & ns & $\overrightarrow{\mathrm{DEC}}$ & ns & $\overline{\mathrm{CED}}$ & ns & $\overline{\text { EDC }}$ \\
\hline
\end{tabular}

ty of shredders was highest at site D, whereas biomass was higher at site $\mathrm{C}$ than $\mathrm{E}$. On the other hand, biomass of gatherers showed the highest value at site $\mathrm{C}$ (table 1). Relevant taxa displayed differences between experimental sites, Nemoura and Echinogammarus being less abundant at site $\mathrm{E}$ than at site D. Heptageniid nymphs, which were absent in January 2000, appeared at this time at all sites.

From January 2000 to January 2001 density and biomass of total macroinvertebrates and most functional groups increased at all sites although it was not always significant (Fig. 3; table 2). In general, site C showed the lowest number of interannual variations among the variables studied, whereas site D registered the highest interannual changes on density and biomass of total macroinvertebrates and most functional groups. At site $\mathrm{E}$ the interannual increases were also significant (table 2) but less strong than at site D. A contrasting pattern was observed in relevant taxa : all of them increased from 2000 to 2001 at site D; only chironomidae, oligochaetes and Nemoura did so at site C; finally, at site E, only chironomids, Leuctra, Protonemura and Limnephilidae increased significantly.

\section{Relationship between macroinvertebrates and organic matter}

Density of macroinvertebrates per amount of organic matter (Ind/g AFDM) was significantly higher at site E than at site C (Fig. 4) in January 2000. No significant differences were found in terms of biomass (mg/g AFDM). Shredder density and biomass did not show differences among sites neither in terms of per total organic matter nor per total leaf matter (Fig. 4 and 5).

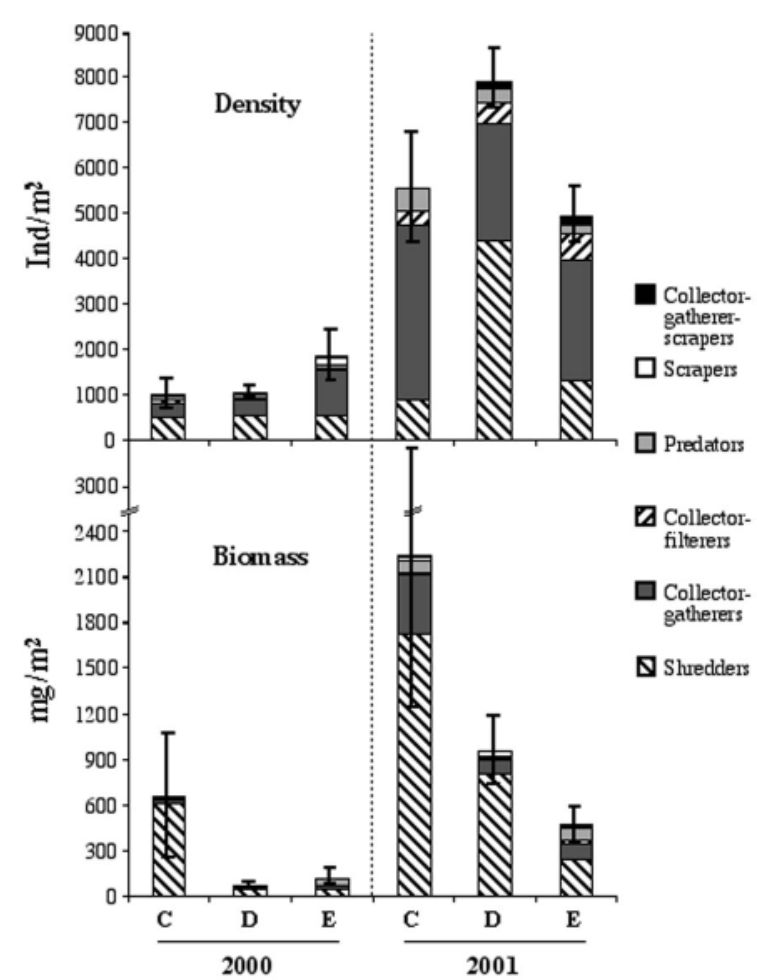

Fig. 3. Mean density and biomass of total macroinvertebrates and functional feeding groups at sites $\mathrm{C}$ (control), D (deciduous) and E (eucalyptus) before (2000) and after (2001) the experimental treatment. Standard errors are indicated for total density and biomass 
Table 2. Results of Student's $t$ for invertebrate density and biomass between years 2000 and 2001 at sites C (control), D (deciduous) and $\mathrm{E}$ (eucalyptus). $* \mathrm{p}<0.05 ; * *: \mathrm{p}<0.01 ; * * *: \mathrm{p}<0.001 ; \mathrm{ns}:$ no significant.

\begin{tabular}{lcccccc}
\hline & \multicolumn{4}{c}{ DENSITY } & \multicolumn{2}{c}{ BIOMASS } \\
\hline & Site & p & Increase & p & Increase \\
\hline \multirow{3}{*}{ Total macroinvertebrates } & C & $* *$ & $446 \%$ & ns & \\
& D & $* * *$ & $607 \%$ & $* * *$ & $1131 \%$ \\
& E & $* *$ & $168 \%$ & $*$ & $288 \%$ \\
\hline \multirow{3}{*}{ Shredders } & C & ns & & ns & \\
& D & $* * *$ & $706 \%$ & $* *$ & $1603 \%$ \\
& E & $*$ & $135 \%$ & ns & \\
\hline \multirow{3}{*}{ Collector-gatherers } & C & $* *$ & $1140 \%$ & $* * *$ & $2960 \%$ \\
& D & $* * *$ & $668 \%$ & $* *$ & $404 \%$ \\
Collector-filterers & E & $* *$ & $172 \%$ & $*$ & $395 \%$ \\
\hline \multirow{3}{*}{ Predators } & C & ns & & $*$ & $-62 \%$ \\
& D & $* *$ & $226 \%$ & ns & \\
& E & $* *$ & $1014 \%$ & $* *$ & $726 \%$ \\
\hline \multirow{2}{*}{ Scrapers } & C & $*$ & $728 \%$ & ns & \\
& D & $* *$ & $404 \%$ & $*$ & $304 \%$ \\
& E & ns & \multicolumn{4}{c}{ ns } \\
\hline
\end{tabular}

In January 2001, total density of macroinvertebrates per organic matter was significantly higher at sites D and $\mathrm{E}$ than at site $\mathrm{C}$, whereas total biomass of macroinvertebrates showed higher values at site $\mathrm{D}$ than at C. Finally, density and biomass of shredders per total organic matter and per total leaf amount was significantly higher at site $\mathrm{D}$.

Statistical analyses did not show interannual changes in density and biomass of total macroinvertebrates and shredders per gram of total organic matter at any site, but the trend observed was to decrease values at sites $\mathrm{C}$ and $\mathrm{E}$ and to increase at site D (Fig. 4). Shredder density per total leaf amount decreased significantly at site E during the experiment (Fig. 5).

\section{Discussion}

Many studies tried to evaluate the impact of changes in riparian vegetation on river macroinvertebrates, but found it difficult to isolate the effects of disturbance from those of natural spatial variability (e.g. Friberg 1997, Kennedy et al. 2000). Natural differences such as in discharge pattern, in channel characteristics, in benthic disturbance regimes, in temperature, in light or in water chemistry, make it difficult to isolate the impact caused by the substitution of forest type (Townsend \& Riley 1999, Beisel et al. 2000). Many factors influence riparian environments, thus making nearly

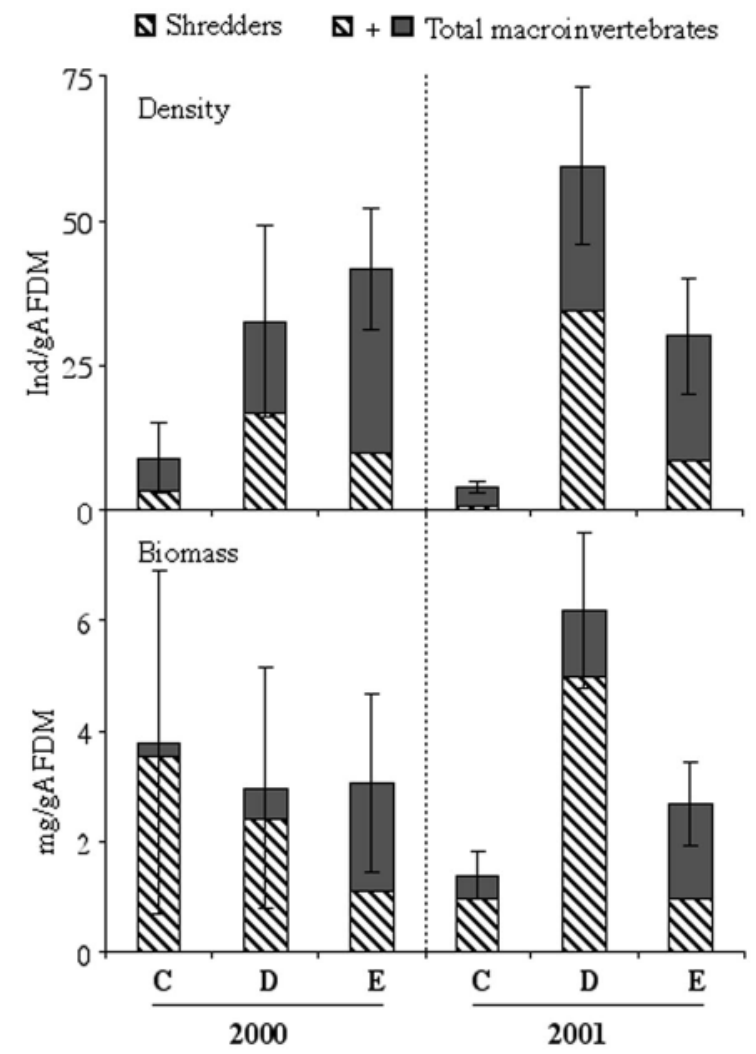

Fig. 4. Mean density and biomass of total macroinvertebrates and shredders per amount of coarse particulate organic matter (Ind/g AFDM and mg/g AFDM) at sites C (control), D (deciduous) and E (eucalyptus) before (2000) and after (2001) the experimental treatment. Standard errors are indicated for total macroinvertebrates.

impossible to find spatially separated reaches with the same characteristics (Margalef 1983, Cooper et al. 1997). To achieve departure conditions as homogenous as possible, we selected three reaches close to each other in the same stream. Our first sampling tested similarity among sites on macroinvertebrate related variables prior to manipulation. The high homogeneity shown by studied variables allowed us to consider these sites as good replicates for the experiment.

Previous studies on the area stressed the importance of the hydrological regime on macroinvertebrate communities in the Agüera basin (Basaguren \& Riaño 1994, Basaguren et al. 1996). Density of macroinvertebrates may be reduced by flow alterations, by spates (Boulton et al. 1992, Imbert \& Perry 2000), as well as by droughts (Wood \& Petts 1999, Humphries \& Baldwin 2003). Due to the climate of the area, floods tend 


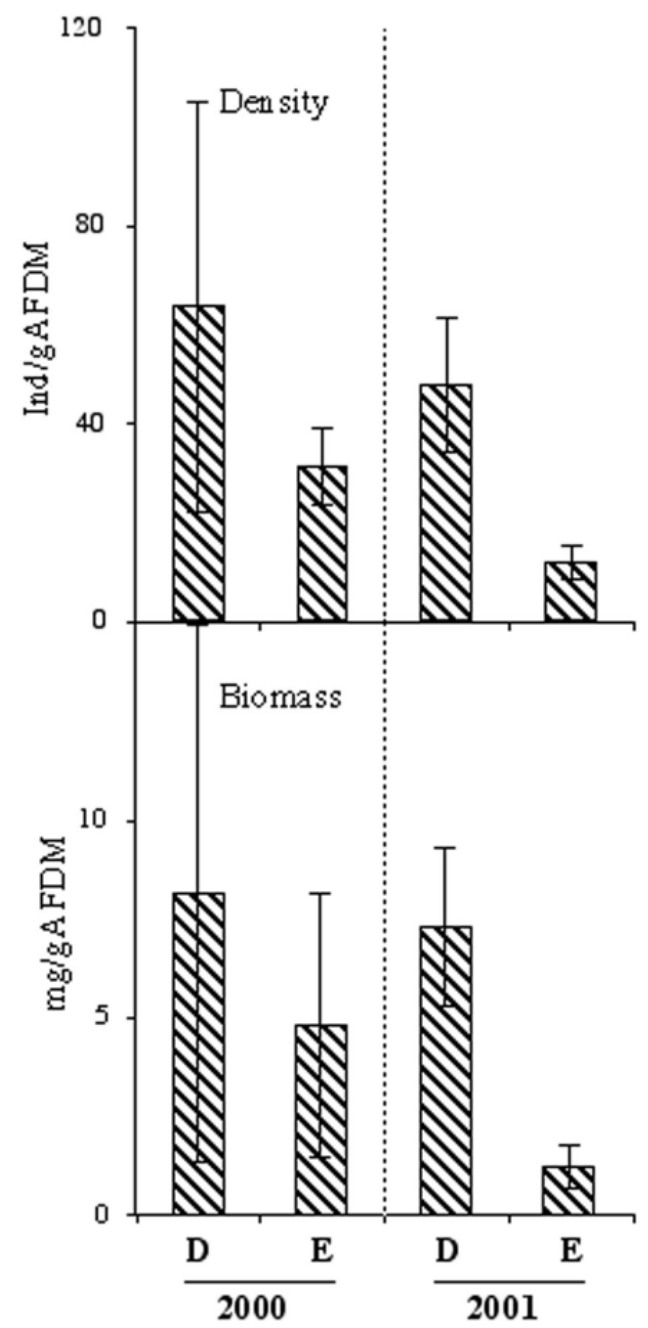

Fig. 5. Mean density and biomass of shredders per gram of benthic leaf litter at sites D (deciduous) and E (eucalyptus) before (2000) and after (2001) the experimental treatment. Standard errors are indicated.

to be frequent from autumn to spring, whereas basal flows occur in summer. Flood magnitude and frequency appeared to be similar before both sampling occasions. Nevertheless, the low discharge period of 1999 , extending from summer to late autumn, was much drier and longer than that in 2000, and reduced the stream water to a few isolated pools. The sampling on January 2000 was performed only 3 months after restoration of river flow. Otermin et al. (2002), in another headwater reach on the Agüera basin, pointed out that density and biomass of macroinvertebrates was still rising 3 months after flow restoration. This could ex- plain the generalised increase in density and biomass of macroinvertebrates at the three sites from 2000 to 2001. Absence of slow colonizing taxa like heptageniids (McArthur \& Barnes 1985, Otermin et al. 2002) in 2000 supports this hypothesis. In addition, the collector-gatherers functional group, that recovers rapidly after droughts (Gore 1982, Otermin et al. 2002), due to the resiliency of chiromomids (Mackay 1992, Katano et al. 1998) and the resistance of oligochaetes (Boulton et al. 1991), showed an extraordinary high interannual increment at all sites.

Organic matter was the variable manipulated in our study through changes in its amount and quality. Several authors describe a close relationship between amount of organic matter and invertebrate density at low order stream reaches (Baer et al. 2001, Rowe \& Richardson 2001). Similarly, positive relationships between organic matter and shredder invertebrates are abundant in the literature (e.g. Hawkins \& Sedell 1981, Murphy \& Giller 2000). Richardson (1991) added extra organic matter to an experimental channel (British Columbia, Canada) and observed a fast increase of shredder density because of increased immigration rate from poorer adjacent places. On the other hand, Wallace et al. $(1997,1999)$ found that the removal of all coarse organic matter from a reach of the Coweeta basin (North Carolina, USA) reduced the density of macroinvertebrates to the tenth part and its biomass to the sixth. Changes in invertebrate density per organic matter at our study sites suggest that the amount of CPOM was not the only factor responsible for differences among sites; other important factors such as quality and timing of leaves should be also important.

Effects of changing autochthonous mixed oak forest litter by eucalyptus litter could be expected at the community level, since Raviraja et al. (1998) and Yeates \& Barmuta (1999) found that consumption and growth rates are reduced in eucalyptus-fed macroinvertebrates irrespective of the functional feeding group. Similarly, Abelho \& Graça (1996) found less macroinvertebrates in reaches below eucalyptus plantations than in reaches under autochthonous deciduous forests. Nevertheless, in our experiment, the substitution of deciduous litter inputs by eucalyptus ones at site E showed no clear effect on density or biomass of the macroinvertebrate community. Lower increases in taxa number, density and/or biomass of total invertebrates, shredders and relevant taxa, or reductions in density and biomass of total invertebrates and shredders per $g$ AFDM in site E with respect to site D, all suggest an impact, but the lack of significant differences in densi- 
ty or biomass between sites D and E, except for shredders, after the experimental manipulation suggest the effect of changes in litter inputs to be detectable but small.

The subtle response of macroinvertebrates to the resource change could be based on different reasons. Firstly, despite the substitution of deciduous by eucalyptus inputs, up to $20 \%$ of the total organic matter amount at site $\mathrm{E}$ was a remnant of deciduous leaf material and only $41 \%$ was eucalyptus litter (see also Bañuelos et al. 2004). A more severe experiment, consisting in the total exclusion of organic matter (Wallace et al. 1997, 1999), showed gradual reductions of macroinvertebrate density that were not statistically significant for certain taxa until the forth year of resource limitation. In addition, if the negative effect of the low nutritional quality of eucalypt litter weakens individuals and reduces their reproductive success, this effect would require several life cycles to be significant, and given the univoltine life cycles of most taxa in the area (e.g. González et al. 2001, 2003a), it could well remain unnoticed unless the experiment was prolonged for several years. All this suggests it is necessary to keep this kind of experiments running for longer periods so as to, if it is the case, detect more generalised significant differences.

On the other hand, oak litter enters our stream naturally, but as in the case of eucalyptus, its processing is slow (Molinero et al. 1996) due to the thick cuticle and the high content of phenolic compounds (Covelo \& Gallardo 2001). Nevertheless, it seems that detritivores consume and efficiently transform oak litter to animal biomass (González \& Graça 2003), but do not conclude its development and die when eat eucalyptus (see Canhoto \& Graça 1995, 1999). This could be the reason to observe significant differences between sites $\mathrm{D}$ and $\mathrm{E}$ in density and biomass of shredders per organic matter or leaf amount, and in density of Echinogammarus and Nemoura. Although it is not a decisive change to clearly detect a negative effect of eucalyptus leaves on macroinvertebrate communities, it could be a first sign of disturbance.

In short, this experiment points that the addition of eucalyptus leaves may affect the functional group of shredders, particularly some taxa, like Echinogammarus and Nemoura. We do not discard that a longer experiment could confirm the negative trends observed in this study. However, our results together with those found in precedent works (Basaguren \& Pozo 1994, González et al. 1998, Pozo et al. 1998) indicate that the impact of eucalyptus plantations on stream invertebrates in the north of Spain is weak because only subt- le differences are found between the invertebrate fauna associated with deciduous and eucalyptus leaf litter.

\section{Acknowledgements}

This research was supported by the Ministry of Education, Culture and Sports (Central Government, Madrid, DGESIC PB98-0151) and the University of the Basque Country (UPV118.310-G14/99). Santiago Larrañaga and Aitor Larrañaga were supported by grants from the Ministry of Education, Culture and Sports.

\section{References}

Abelho M. \& Graça M.A.S. 1996. - Effects of eucalyptus afforestation on leaf litter dynamics and macroinvertebrate community structure of streams in Central Portugal. Hydrobiologia, 324, 195204.

Baer S.G., Siler E.R., Eggert S.L. \& Wallace J.B. 2001. - Colonization and production of macroinvertebrates on artificial substrata upstream-downstream responses to a leaf litter exclusion manipulation. Freshwater Biol., 46, 347-365.

Bañuelos R., Larrañaga S., Elosegi A. \& Pozo J. 2004. - Effects of eucalyptus plantations on CPOM dynamics in headwater streams : a manipulative approach. Arch. Hydrobiol., 159, 211228.

Bärlocher F., Canhoto C. \& Graça M.A.S. 1995. - Fungal colonization of alder and eucalypt leaves in two streams in Central Portugal. Arch. Hydrobiol., 133, 457-470.

Basaguren A. \& Pozo J. 1994. - Leaf litter processing of alder and eucalyptus in the Agüera stream system (Northern Spain) II. Macroinvertebrates associated. Arch. Hydrobiol., 132, 57-68.

Basaguren A. \& Riaño P. 1994. - Trophic structure of the macroinvertebrate communities in the Agüera Stream (Northern Spain) Verh. Internat. Verein. Limnol., 25, 1727-1732.

Basaguren A., Elósegui A. \& Pozo J. 1996. - Changes in the trophic structure of benthic macroinvertebrate communities associated with food availability and stream flow variations. Int. Revue ges. Hydrobiol., 81, 1-12.

Beisel J.N., Usseglio-Polatera P. \& Moreteau J.C. 2000. - The spatial heterogeneity of river bottom : a key factor determining macroinvertebrate communities. Hydrobiologia, 422/423, 163-171.

Boulton A J., Stibbe S.E., Grimm N.B. \& Fisher S.G. 1991. - Invertebrate recolonization of small patches of defaunated hyporheic sediments in a Sonoran Desert stream. Freshwater Biol., 26, 267277.

Boulton A.J., Peterson C.G., Grimm N.B. \& Fisher S.G. 1992. - Stability of an aquatic macroinvertebrate community in a multiyear hydrologic disturbance regime. Ecology, 73, 2192-2207.

Canhoto C. \& Graça M.A.S. 1995. - Food value of introduced eucalypt leaves for a Mediterranean stream detritivore : Tipula lateralis. Freshwater Biol., 34, 209-214.

Canhoto C. \& Graça M.A.S. 1999. - Leaf barriers to fungal colonization and shredders (Tipula lateralis) consumption of decomposing Eucalyptus globulus. Microbial Ecol., 37, 163-172.

Chauvet E., Fabre E., Elósegui A. \& Pozo J. 1997. - The impact of eucalypt on the leaf associated aquatic hyphomycetes in Spanish streams. Can. J. Botany, 75, 880-887.

Cooper S.D., Barmuta L., Sarnelle O., Kratz K. \& Diehl S. 1997. Quantifying spatial heterogeneity in streams. J. N. Am. Benthol. Soc., 16, 174-188.

Covelo F. \& Gallardo, A. 2001. - Temporal variation in total leaf phenolics concentration of Quercus robur in forested and harvested stands in northwestern Spain. Can. J. Botany, 79, 1262-1269.

Elosegi A., Basaguren A. \& Pozo J. 2002. Ecology of the Agüera : a review of fourteen years of research in a Basque stream. Munibe, $53,15-38$. 
Friberg N. 1997. - Benthic invertebrate communities in six Danish forest streams : impact of forest type on structure and function. Ecography, 20, 19-28.

Giller P.S. \& Twomey H. 1993. - Benthic macroinvertebrate community organisation in two contrasting rivers - site differences and seasonal patterns. Biol. Environ., 93, 115-126.

González J.M., Basaguren A. \& Pozo J. 1998. - Mechanisms involved in leaf litter processing : influence of bag mesh size. Pages 89-97 in Advances in River Bottom Ecology. Bretschko G. \& Helesic J. (eds). Backhuys Publishers, Leiden.

González J.M., Basaguren A. \& Pozo J. 2001. - Life history and production of Caenis luctuosa (Burmeister) (Ephemeroptera, Caenidae) in two nearby reaches along a small stream. Hydrobiologia, 452, 209-215.

González J.M., Basaguren A. \& Pozo J. 2003a. - Life history, production and coexistence of two leptophleiid mayflies in three sites along a Northern Spain stream. Arch. Hydrobiol., 158, 303-316.

González J.M., Basaguren A. \& Pozo J. 2003b. - Macroinvertebrate communities along a third-order Iberian stream. Ann. Limnol. Int. J. Lim., 39, 287-296.

González, J.M. \& Graça M.A.S. 2003. - Conversion of leaf litter to secondary production by a shredding caddis-fly. Freshwater Biol., 48, 1578-1592.

Gore J.A. 1982 - Benthic invertebrate colonization : source distance effects on community composition. Hydrobiologia, 94, 183-193.

Graça M.A.S. 2001. - The role of invertebrates on leaf litter decomposition in streams - a review. Internat. Rev. Hydrobiol., 86, $383-$ 393.

Hall R.O., Wallace J.B. \& Eggert S.L. 2000. - Organic matter flow in stream food webs with reduced detrital resource base. Ecology, 81, 3445-3463.

Hawkins C.P. \& Sedell J.R. 1981. - Longitudinal and seasonal changes in functional organization of macroinvertebrate communities in four Oregon streams. Ecology, 62, 367-397.

Humphries P. \& Baldwin D.S. 2003. - Drought in aquatic environments. Freshwater Biol., 48,1141-1283.

ICONA. 1980. - Las frondosas en el Primer Inventario Forestal Nacional. Ministerio de Agricultura. Subdirección General de Protección de la Naturaleza, Madrid.

Imbert J.B. \& Perry J.A. 2000. - Drift and benthic invertebrate responses to stepwise and abrupt increases in non-scouring flow. $\mathrm{Hy}$ drobiologia, 436, 191-208.

Katano O., Toi J., Maekawa K. \& Iguchi K. 1998. - Colonization of an artificial stream by fishes and aquatic macro-invertebrates. Ecol. Res., 13, 83-96.

Kennedy T.B., Merenlender A.M. \& Vinyard G.L. 2000. - A comparison of riparian condition and aquatic invertebrate community indices in Central Nevada. West. N. Am. Naturalist, 60, 255-272.

Lamb R.J. 1985. - Litter fall in two eucalypt woodlands. Aust. J. Bot., 33, 1-14

Mackay R.J. 1992. Colonization by lotic macroinvertebrates : a review of processes and patterns. Can. J. Fish. Aquat. Sci., 49, $617-$ 626.

Margalef R. 1983. - Limnología. Omega, Barcelona, 1010 p.

McArthur J.V. \& Barnes J.R. 1985. - Patterns of macroinvertebrate colonization in an intermittent Rocky Mountain stream in Utah. Great Basin Nat., 45, 117-123.

Merritt R.W. \& Cummins K.W. 1996. - An introduction to the aquatic insects of North America. Kendall-Hunt Publishing Company, Dubuque, $862 \mathrm{p}$.

Molinero J., Pozo J. \& Gonzalez E. 1996. - Litter breakdown in streams of the Agüera catchment : influence of dissolved nutrients and land use. Freswater Biol., 36, 745-756.

Molinero J. \& Pozo J. 2004. - Impact of a eucalyptus (Eucalyptus globulus Labill.) plantation on the nutrient content and dynamics of coarse particulate organic matter (CPOM) in a small stream. Hydrobiologia, 528, 143-165.

Murphy J.F. \& Giller P.S. 2000. - Seasonal dynamics of macroinvertebrate assemblages in the benthos and associated with detritus packs in two low order streams with different riparian vegetation. Freshwater Biol., 43, 617-631.

O’Connell A.M. \& Menagé P.M.A. 1982. - Litter fall and nutrient cycling in karri (Eucalyptus diversicolor $\mathrm{F}$. Muell.) forest in relation to stand age. Aust. J. Ecol., 7, 49-62.

Otermin A., Basaguren A. \& Pozo J. 2002. - Re-colonization by the macroinvertebrate community after a drought period in a first-order stream (Agüera basin, northern Spain). Limnetica, 21, 117 128.

Paiva J. 1992. - As plantacións de eucaliptos e a flora e fauna portuguesa. Cad. Cien. Biol., Seminario de Estudos Galegos, 4, 71-84.

Pozo J. 1993. - Leaf litter processing of alder and eucalyptus in the Agüera stream system (North Spain) I. Chemical changes. Arch. Hydrobiol., 127, 299-317.

Pozo J., González E., Díez J.R., Molinero J. \& Elósegui A. 1997. Inputs of particulate organic matter to streams with different riparian vegetation. J. N. Am. Benthol. Soc., 16, 602-611.

Pozo J., Basaguren A., Elósegui A., Molinero J., Fabre E. \& Chauvet E. 1998. - Afforestation with Eucalyptus globulus and leaf litter decomposition in streams of northern Spain. Hydrobiologia, 373/374: 101-109

Raviraja N.S., Sridhar K.R. \& Bärlocher F. 1998. - Breakdown of Ficus and Eucalyptus leaves in an organically polluted river in India : fungal diversity and ecological functions Freshwater Biol., 39, 537-545.

Richardson J.S. 1991. - Seasonal food limitation of detritivores in a montane stream : an experimental test. Ecology, 72, 873-887.

Rowe L. \& Richardson J.S. 2001. - Community responses to experimental food depletion : resource tracking by stream invertebrates. Oecologia, 129, 473-480.

Royer T.V., Monaghan M.T. \& Minshall G.W. 1999. - Processing of native and exotic leaf litter in Idaho (U.S.A.) streams. Hydrobiologia, 400, 123-128.

Tait C.K., Li J.L., Lamberti G.A., Pearsons T.N. \& Li H.W. 1994. Relationships between riparian cover and the community structure of high desert streams. J. N. Am. Benthol. Soc., 13, 45-56.

Townsend C.R. \& Riley R.H. 1999. - Assessment of river health : accounting for perturbation pathways in physical and ecological space. Freshwater Biol., 41, 393-405.

Wallace J.B., Eggert S.L., Meyer J.L. \& Webster J.R. 1997. - Multiple trophic levels of a forest stream linked to terrestrial litter inputs. Science, 277, 101-104.

Wallace J.B., Eggert S.L., Meyer J.L. \& Webster J.R. 1999. - Effects of resource limitation on a detrital-based ecosystem. Ecol. Monogr., 69, 409-442.

Wood P.J. \& Petts G.E. 1999. - The influence of drought on chalk stream macroinvertebrates. Hydrol. Process., 13, 387-399.

Yeates L.V. \& Barmuta L.A. 1999. - The effects of willow and eucalypt leaves on feeding preference and growth of some Australian aquatic macroinvertebrates. Aust. J. Ecol., 24, 593-598.

Zar J.H. 1999. - Biostatistical analysis. Fourth edition. Prentice Hall, Upper Saddle River, New Jersey 